\title{
Impact of wildfires on the megafauna of Emas National Park, central Brazil
}

\author{
Leandro Silveira, Flávio Henrique G. Rodrigues, Anah Tereza de Almeida Jácomo and \\ José Alexandre F. Diniz Filho
}

\begin{abstract}
This study evaluates the impact of two wildfires, in 1994 and 1995, on the large mammal fauna of Emas National Park, central Brazil. The 1994 fire burned 100 per cent of the park's grassland and after the fire, in a c. 2000-ha survey area, the authors found 16 giant anteaters Myrmecophaga tridactyla, two giant armadillos Priodontes maximus and one tapir Tapirus terrestris that had died in the fire. The 1995 fire burned 15 per cent of the park's grassland and no dead animals were found in a 220-ha survey area. The authors discuss the possible long-term ecological consequences of
\end{abstract}

wildfires on the large mammal fauna of Emas, with a special focus on the giant anteater population, which is particularly susceptible to fires. They recommend a fire management programme, which would include controlled burns on a rotational basis in different sections of the park. The programme would also improve the availability of food for herbivores and control the spread of alien grass species.

Keywords Cerrado, Emas National Park, fire management, giant anteater, wildlife management.

\section{Introduction}

Central Brazil is dominated largely by the cerrado biome, the country's second most extensive vegetation type after the Amazonian forest (Eiten, 1972). The cerrado is generally described as a mosaic of grassland, shrub and scattered low twisted trees (cerrado sensu stricto), marshes and strips of gallery forest along water drainage. For a detailed description of cerrado vegetation see Eiten (1972, 1990). Wildfire is a natural factor shaping tropical savannahs and has been present in the cerrado for at least the past 34,000 years (Ribeiro, 1994). The flora and fauna of the cerrado have evolved with fire, resulting in several plant species that can tolerate high temperatures (Warming \& Ferri, 1973). Coutinho (1990) suggested that the colour patterns of several cerrado mammals may be adapted for camouflage in post-fire conditions. Studies have been carried out on the effects of fire on the cerrado flora (Coutinho, 1982, 1990; Rosa, 1990; Sanaiotti \& Magnusson, 1995), but the impact of fire on the fauna is poorly understood (Borchert \& Hansen, 1983; Figueiredo, 1991; Vieira,

Leandro Silveira, Anah Tereza de Almeida Jácomo, José Alexandre F. Diniz Filho Universidade Federal de Goiás, Departamento de Biologia Geral, CP 131, 74001-970, Goiánia-GO, Brazil. E-mail: silveira@icb1.ufg.br

Flávio Henrique G. Rodrigues Universidade Estadual de Campinas, Departamento de Zoologia, CP 6109, 13083-970, Campinas-SP, Brazil

Received 6 November 1997. Accepted 2 August 1998
1994). Even less research has been conducted on large mammals, although Drumond (1992) investigated the effects of fire on foraging activities of giant anteaters.

Lightning is a major cause of natural fires in most ecosystems, although spontaneous combustion may also occur (Boerner, 1982; Coutinho, 1982). In central Brazil indigenous people regularly used controlled fires as a hunting tool (Anderson \& Posey, 1991), and since early colonial times ranchers have used fire to improve pastures (Eiten, 1972; Coutinho, 1982). The impact of a wildfire depends on the intensity and duration of burning, which in turn depend on fuel load (above ground biomass and detritus), fuel moisture, weather and topography (Bendell, 1974). Considering this, each fire is unique in terms of its local impact, making it difficult to extrapolate from data collected in one area of cerrado to other, distant, areas.

Emas National Park (ENP) is known for the ease with which large mammals may be seen and for the great fires that, every 3-4 years or so, burn at least 60 per cent of its area (Erize, 1977; IBDF/FBCN, 1981; Redford, 1985). Fires lit by cattle ranchers at the end of the dry season in the region of ENP to provide fresh grazing usually run out of control and move into the park. Emas National Park suffered its first catastrophic fire in 1975. Before this year, grazing by livestock inside the park restricted the accumulation of dry vegetation, thus limiting the intensity of fires. Since 1975 the park has suffered periodic fires, at c. 3-year intervals. These are normally preceded by a frost that kills most of the foliage, creating a greater fuel load (A. M. Cruz, pers. comm.).

The largest fires registered in Emas prior to 1994 
were in 1978 , when in $30 \mathrm{~h} 100$ per cent of the park went up in flames, and in 1988, when fire also burned 100 per cent of the park. No systematic studies were carried out after these fires to investigate their impact on the fauna, but dead giant anteaters Myrmecophaga tridactyla, a jaguarundi Herpailurus yaguaroundi, a whitelipped peccary Tayassu pecari and a hog-nosed skunk Conepatus semistriatus were recorded, and a puma Puma concolor was found with burn injuries, alive on a tree (Redford, 1985; A. M. Cruz, pers. comm.). In August 1994 a fire burned 100 per cent of the grassland of ENP, which corresponds to c. 97 per cent of its total area. In August 1995 another fire burned c. 15 per cent of the park's grasslands. This study evaluates the effects of the 1994 and 1995 fires on the large mammals and suggests strategies for a fire management programme for ENP in order to minimize the impact of fire on its fauna.

\section{Study site}

Emas National Park was established in 1961 in the extreme south-west of the state of Goias (18 $19^{\prime} \mathrm{S}$, $52^{\circ} 45^{\prime} \mathrm{W}$ ) and is the largest piece of continuous preserved cerrado in a protected area. Its 131,868 ha contain a great variety of habitats, but predominantly (97 per cent) rolling grassland, with small patches of cerrado (sensu stricto), marshes and gallery forest. Approximately $1500 \mathrm{~mm}$ of rain falls during the wet season, from September to May (IBDF/FBCN, 1981). Virtually no rain falls in the dry season between June and August, when temperatures reach $39^{\circ} \mathrm{C}$ during the day and may drop to $-1^{\circ} \mathrm{C}$ at night (F.H.R., unpublished data).

\section{Methods}

\section{4 survey for dead anteaters}

The fire that started on 14 August 1994 burned 127,912 ha (100 per cent) of the grasslands of ENP, or 97 per cent of the total area, in 4 days. To estimate the number of large mammals killed by this fire, on 27 August we carried out a vehicle survey in 2052 ha of grasslands, using $342 \mathrm{~km}$ of roads inside the park as a transect line (Fig. 1). Transect width was calculated by the software DISTANCE (Laake et al., 1993) according to methodology described in Burnham et al. (1980). Two observers, one on each side, scanned both sides of the transect, recording the perpendicular distance from the transect of every burned mammal carcass. This survey was concluded in 2 days. Carcasses found outside the transect area and information on burned mammals in the park's vicinity were noted separately.
Carcasses were observed at distances of 10-30 m from the transect line. To estimate the density of burned animals the program DISTANCE was used to calculate the transect width by using the perpendicular distances from the transect line of observed carcasses grouped into three intervals $(0-10,11-20,21-30 \mathrm{~m})$, and using a half-normal estimator as described by Burnham et al. (1980). We used the total grassland area of the park, 127,912 ha, to estimate density.

\section{5 survey for dead anteaters}

The burning of the entire park in 1994 had substantially reduced the fuel load for the fire of 25 August 1995, which burned c. 15 per cent $(19,187$ ha) of the park's grasslands. To survey carcasses of animals killed by the fire we established several transects in the burned area, because there were no roads in this site, and used the same vehicle and observers as for the 1994 survey. Transects covered a total length of $36.8 \mathrm{~km}$ and a total area of 220 ha $(0.17$ per cent of the park's grassland area), calculated by estimating the transect width as $60 \mathrm{~m}$ ( $30 \mathrm{~m}$ either side), based on the maximum distance from the transect of carcasses observed after the 1994 fire.

\section{Survey for live anteaters after the 1994 fire}

To estimate the density of live giant anteaters after the 1994 fire, we conducted a vehicle survey using a park road of $49 \mathrm{~km}$ through grassland habitat as a transect line. We surveyed the transect 69 times, at a regular speed of $40 \mathrm{~km} / \mathrm{h}$, during daylight from August 1994 to July 1995. Not all surveys covered the total transect length.

Animals were observed at distances of $45-270 \mathrm{~m}$ from the transect line. The perpendicular distances from the transect of sighted animals were noted and grouped in six intervals $(0-50,51-100,101-150,151-$ $200,201-250,251-300 \mathrm{~m}$ ) according to the prerequisites of the software used to calculate the density, which calculated the transect width automatically. The burned fields allowed a better view than is usually possible because the tall grass had been removed, but it is worth noting that the black coats of giant anteaters offer good camouflage in the burned grassland. To minimize possible bias caused by the growth of grass during the 10-month survey period, we grouped the transect data into three periods (August-September, OctoberNovember, December-May), and estimated densities for each period. The difference in transect widths between this survey and the survey of burned anteaters is the result of it being easier to see a live animal than a carcass lying on the ground. However, the software 


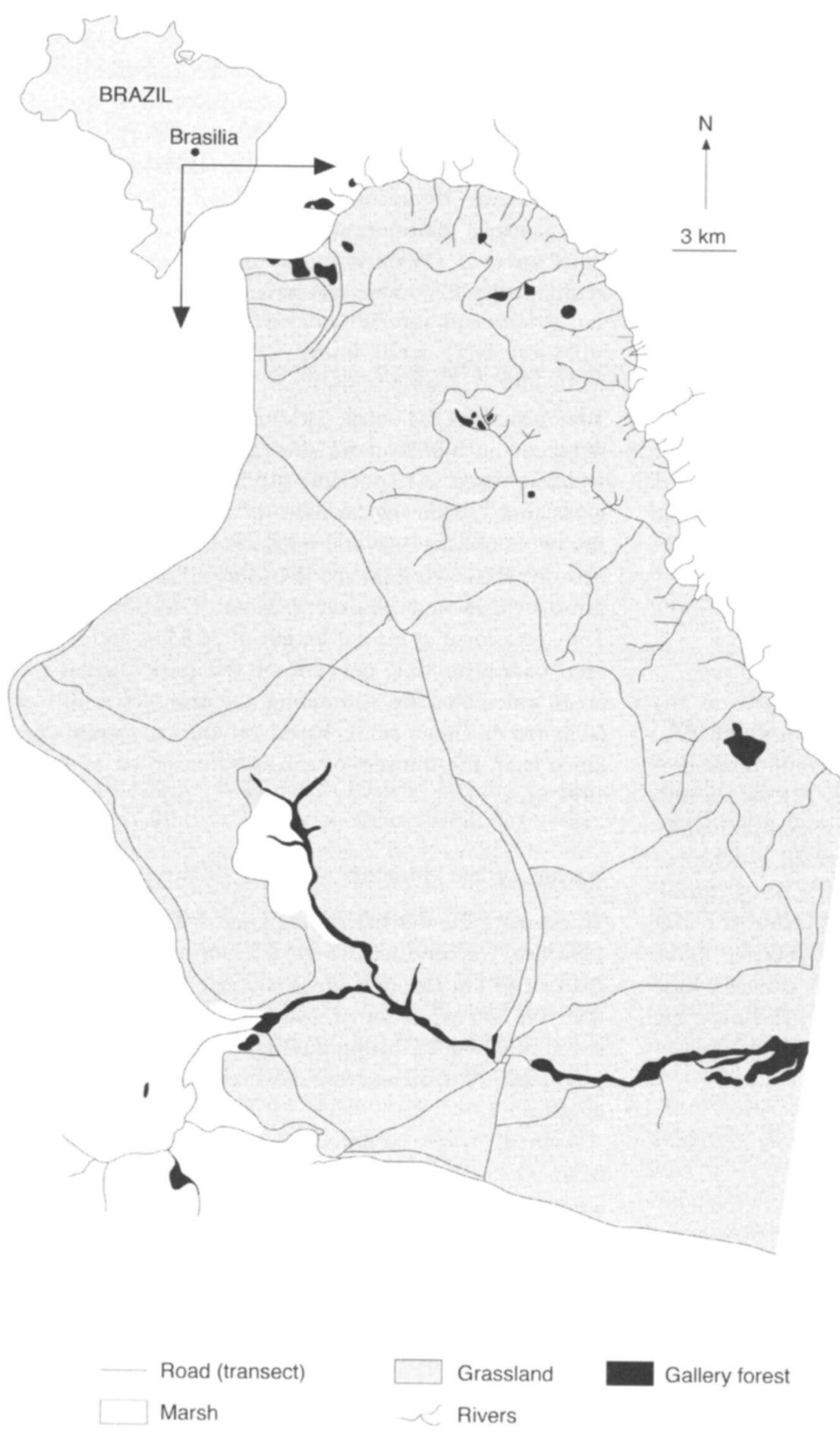

Fig. 1 Emas National Park, central Brazil.

used is robust in calculating the transect width. The density estimate and computer analysis were processed using the same method and software (described above) used to estimate the number of burned anteaters. As before, we used only the total area of grassland, rather than the total area of the park, to calculate the population size.

\section{Results}

1994 survey for dead animals

We found the following carcasses in the transect survey in August 1994: 13 giant anteaters, two giant armadillos Priodontes maximus and a juvenile tapir Tapirus terrestris. 
Table 1 Estimated densities of giant anteaters after the August 1994 fire in ENP

\begin{tabular}{llll}
\hline Period & $\begin{array}{l}\text { Density } \\
\text { (individuals/ha) }\end{array}$ & $\begin{array}{l}95 \% \text { confidence interval } \\
\text { (individuals/ha) }\end{array}$ & $\begin{array}{l}\text { Estimated number } \\
\text { of giant anteaters }\end{array}$ \\
\hline August-September & 0.00034 & $0.00015-0.00078$ & 43 \\
October-November & 0.00079 & $0.00046-0.00136$ & 101 \\
December-May & 0.00085 & $0.00037-0.00193$ & 109 \\
\hline
\end{tabular}

The estimated density of giant anteaters killed by the fire in the total grassland area of the park was 0.0063 individuals/ha $(95 \%$ confidence interval $0.0026-$ 0.016 individuals/ha), or approximately 810 individuals. The sample sizes of armadillo and tapir carcasses were too small for statistical analysis.

Eleven carcasses of burned giant anteaters were found outside the surveyed area. A local farmer reported another individual that had escaped from the park but had died soon afterwards as the result of severe burns. There were reports of two pampas deer Ozotocerus bezoarticus: one was burned to death and the other was alive but had severe burns and parts of its hooves missing. Between 19 and 21 August we found three carcasses of giant anteaters inside the park with no apparent signs of predation or wounds caused by burning.

\section{5 survey for dead animals}

After the fire of 25 August 1995, no burned mammals were found on our transects. On 30 August an accidental fire on private land ran out of control and burned a large area of marsh in the vicinity of ENP. At least one marsh deer Blastocerus dichotomus was found burned to death and a maned wol f Chrysocyon brachyurus was observed alight, running along a fire line towards a dead end.

\section{Survey for live anteaters}

In the months after the 1994 fire the giant anteater density apparently increased (Table 1).

\section{Discussion}

Even being conservative and considering the lowest estimated number of giant anteaters killed by the fire of August 1994, 332 individuals (lowest confidence limit for dead anteaters $0.0026 \times 127,912$ ), we may conclude that this fire was extremely harmful for the anteater population of the park. The species is very susceptible to fire because of its slowness and its inflammable fur. It is classified as Vulnerable (IUCN, 1996), and significant populations are found only in the Pantanal in western Brazil, Serra da Canastra National Park and ENP (Fonseca et al., 1994). This termite- and ant-feeding specialist has a low metabolic rate, generally one offspring, long-term parental care and a gestation period of 190 days (Drumond, 1992). All these factors combine to give an intrinsic low population growth rate (McNab, 1984). Considering this, although our data show a population increase between September 1994 and May 1995 (Table 1), this cannot be the result of natural reproductive recovery. It must be a result of recolonization through local migration of individuals that escaped the fire. Giant anteaters can escape from fires by taking refuge in gallery forest along river banks or fleeing across farmland surrounding the park. Another explanation for the apparent rapid recovery in numbers between the first and second census dates could be because anteaters were camouflaged in the recently burned environment and this would have affected our ability to detect them during the first census period (August-September 1994), resulting in a biased sample for that period.

Because there were no data available on giant anteater density in ENP prior to the fire of 1994, we were unable to evaluate more precisely the impact of the fire on this species. However, Shaw et al. (1987) found a population density of at least 0.013 giant anteaters/ha in Serra da Canastra National Park. If we assume the same density for ENP in its entire 131,868 ha, it would give a population size of 1714 giant anteaters before the fire. The total area of the park has been used to estimate the population size because giant anteaters use other cerrado habitats as well as grassland (Shaw et al., 1987). Subtracting the estimated number of anteaters killed by the fire (810) from an estimated population size of 1714 would leave 904 giant anteaters in the park after the fire. This number is much higher than the average calculated numbers of live giant anteaters (109) in ENP during the period of the third census (December 1994-May 1995; Table 1), suggesting that the original population was smaller than that of Serra da Canastra National Park.

The pampas deer and the tapir are less vulnerable to fire, probably because they can detect fire and run from the flames more rapidly. The giant armadillo is also less likely to be affected because of its fossorial habits. Nevertheless, the 1994 fire was so intense and fast that it killed these species too. 
We assumed that the three dead giant anteaters found a few days after the 1994 fire died as the result of indirect effects of fire (breathing problems due to smoke, undetectable physical injury or stress), because no signs of predation were observed. This indicates that this species may also be vulnerable to indirect effects of wildfires.

Large amounts of dry plant matter accumulate if fires are absent for a period of 3 years, which results in enough fuel for an intense fire (Ramos-Neto \& Pinheiro-Machado, 1996). Grasses such as Tristachya leiostachya grow to over $3 \mathrm{~m}$ tall. Under these conditions fires may run out of control and burn the entire park. Many animals burn to death, while others may suffer post-fire consequences, such as shortage of food, exposure to predators and dehydration. Brynard (1971) reported a similar situation in the African savannah, where uncontrolled fires burned and killed large game species, such as elephant, lion and warthog.

We did not measure the impact of the 1994 fire on small vertebrates, but we believe that there were losses. We frequently observed rodents crossing the roads and fields during daylight, and occasionally being preyed on by raptors. Other vertebrates, such as the fossorial lizard Ophiodes striatus, also became easy prey for birds and mammals. Several snakes, lizards and frogs were found dead after the fire. One dead anaconda Eunectes murinus with burn marks was seen floating on one of the park's rivers minutes after the fire.

No dead animals were found after the fire of August 1995. The burning of the entire park area in the previous year had substantially reduced the fuel load, producing a small intensity fire, which apparently did not harm the escaping megafauna. Patches of vegetation were left intact and may have served as refuges. Borchert \& Hansen (1983) and Friend (1993) mentioned the importance of these patches of vegetation, left intact in small fires, as sources for recolonization by communities of small mammals.

In ENP, pampas deer have been observed jumping narrow fire lines and immediately grazing close by (Coutinho, 1980; A. M. Cruz, pers. comm.) and during the 1994 fire, radio-tagged pampas deer were located in the burned area a few hours after the passage of fire (Rodrigues, 1996a). Drumond (1992) found no negative effects of small wildfires on the giant anteater population of Serra da Canastra National Park. Nevertheless, the 1994 fire in ENP, because of its intensity, proved to be extremely harmful to the local fauna.

We believe that the best way to avoid catastrophic fires in ENP is to develop a fire management pro- gramme. This recommendation was described in the park's management plan (IBDF/FBCN, 1981) and by others (Schaller, 1976; Erize, 1977; Redford, 1985; Coutinho, 1990) as an urgent need, but it has not yet been implemented. The park is almost a cerrado island amid soybean plantations, another factor that renders the megafauna populations even more prone to extinction, because the effect of fire on isolated populations is obviously greater and immigration is more limited.

\section{Recommendations for fire management in ENP}

1 We suggest that the park be divided into large sections, using the $342 \mathrm{~km}$ of interior roads as limits and fire breaks (Fig. 1). Alternate sections should be burned on an annual rotation, so that each section would be burned every 3 years. The best time for this would be at the start of the dry season (May), when the vegetation is dry enough for a fire but when it can still be controlled. This period does not coincide with the nesting or breeding season of most species. Important fruit species such as Anacardium, Duguetia and Parinari, which flower between June and August, would not be adversely affected by burning in this period. These plant species play important roles in the diet of several species of vertebrates in the park (L.S. and A.J., unpublished data).

2 We favour letting fires that are started by lightning continue to burn, because the weather conditions, which are usually followed by rain, would probably result only in a small fire.

3 Studies of efficient strategies to control invasion of exotic grasses, such as Brachiaria spp., Hyparrhenia spp. and Melinis spp., should be encouraged. These species not only displace the native species but also produce greater amounts of dry matter in the dry season than the native grasses.

4 Buffer zones should be established to improve control of fires and grass invasion. The western and southern limits of the park are delimited by fences along $42 \mathrm{~km}$ of two highways. The absence of a buffer zone permits alien grasses to invade the park easily. Seeds may be carried by rain, wind, animals or vehicles.

A periodic, controlled burn would not only minimize the danger of uncontrolled fires but would also ensure a supply of fresh vegetation for herbivores during the dry season (Rodrigues, 1996b). This would limit the need for animals such as the pampas deer and the flightless rhea Rhea americana to leave the park to feed on the crops of adjacent farms. Such behaviour increases the chances of being killed on the roads, hunted or poisoned by pesticides. 
There is no legislative provision allowing controlled fires in protected areas and the government institute responsible for protected areas (IBAMA-Instituto Brasileiro do Meio Ambiente e Recursos Naturais Reno- váveis) is resistant to the use of fires because of potential wildlife mortality. However, this stance may actually increase wildlife losses in ENP indirectly by permitting the habitat to deteriorate, change or succeed to a less productive vegetational stage. A fire management plan in ENP would prevent the invasion of Brachiaria and other introduced grasses, and might inhibit the total dominance of the native tall capimflecha grass Tristachya leiostachya, which was once confined to small patches in the park (Ramos-Neto \& Pinheiro-Machado, 1996). Fire exclusion programmes may result in exceptionally destructive fires, by permitting abnormally heavy build-up of fuel, and vegetation deterioration. These directly affect populations of rare species such as giant anteaters and giant armadillos and may jeopardize their ultimate survival in the park.

\section{Acknowledgements}

We thank Emerson Vieira, Kent Redford, Peter Crawshaw and Divino Brandão for comments on earlier drafts of the manuscript. Antônio Malheiros da Cruz, former director of ENP, and José Carlos kindly provided historical fire data for the park. Wanderlei Gramma and Ary S. Santos gave valuable logistical support during the 1994 and 1995 surveys, respectively.

\section{References}

Anderson, A.B. \& Posey, B.A. (1991) Reflorestamento indígena. Ciência Hoje, Edição Especial-Amazônia, pp. 6-12.

Bendell, J.F. (1974) Effect of fire on birds and mammals. In Fire and Ecosystems (eds T. T. Kozlowski and C. E. Ahlgen), pp. 73-138. Academic Press, New York.

Boerner, R.E.J. (1982) Fire and nutrient cycling in temperate ecosystems. BioScience, 32(3), 187-192.

Borchert, M. \& Hansen, R.L. (1983) Effects of flooding and wildfire on valley side wet campo rodents in central Brazil. Revista Brasileira de Biologia, 43(3), 229-240.

Brynard, A.M. (1971) Controlled burning in the Kruger National Park: history and development of a veld burning policy. In Proceedings of the 11th Annual Tall Timbers Fire Ecology Conference, pp. 219-231. Tall Timbers Research Station, Tallahasee, USA.

Burnham, K.P., Anderson, D.R. \& Laake, J.K. (1980) Estimation of density from line transect sampling of biological populations. Wildife Monographs, 72, 1-202.

Coutinho, L.M. (1980) As queimadas e seu papel ecológico. Brasil Florestal, 44, 7-23.
Coutinho, L.M. (1982) Ecological effects of fire in Brazilian cerrado. In Ecology of Tropical Savannas (eds B. J. Huntley and B. H. Walker), pp. 273-291. Springer-Verlag, Berlin.

Coutinho, L.M. (1990) Fire in the ecology of the Brazilian cerrado. In Fire in the Tropical Biota Ecosystem: Processes and Global Changes (ed. J. G. Goldammer), pp 82-105. Springer-Verlag, Berlin.

Drumond, M.A. (1992) Padrões de forrageamento do tamanduá bandeira (Myrmecophaga tridactyla) no Parque Nacional da Serra da Canastra: dieta, comportamento alimentar e efeito de queimadas. MSc thesis, Universidade Federal de Minas Gerais, Brazil.

Eiten, G. (1972) The cerrado vegetation of Brazil. Botanical Review, 38, 201-341.

Eiten, G. (1990) Cerrado-Vegetação. In Cerrado, Caracterização, Ocupação e Perspectivas (ed. M. N. Pinto), pp. 9-65. Editora Universidade de Brasília, Distrito Federal.

Erize, F. (1977) Brazil's finest national park. Oryx, 13, $457-462$

Figueiredo, S.V. (1991) Efeito de fogo sobre o comportamento e sobre a estrutura da avifauna de cerrado. MSc thesis, Universidade de Brasília, Departamento de Ecologia, Brazil.

Fonseca, G.A.B., Rylands, A.B., Costa, C.M.R., Machado, R.B. \& Leite, Y.L.R. (1994) Livro Vermelho dos Mamiferos Brasileiros Ameaçados de Extinção. Fundação Biodivérsitas, Belo Horizonte, MG.

Friend, G.R. (1993) Impact of fire on small vertebrates in mallee woodlands and heathlands of temperate Australia: a review. Biological Conservation, 65, 99-114.

IBDF/FBCN (1981) Plano de Manejo: Parque Nacional das Emas. Instituto Brasileiro do Meio Ambiente e Recursos Naturais Renováveis, Brasília.

IUCN (1996) 1996 IUCN Red List of Threatened Animals. IUCN, Gland, Switzerland.

Laake, J.L., Buckland, S.T., Anderson, D.A. \& Burnham, K.P. (1993) DISTANCE User's Guide V2.0. Colorado Cooperative Fish and Wildlife Research Unit, Colorado State University, Fort Collins, CO, USA.

McNab, B.K. (1984) Physiological convergence among ant-eating and termite-eating mammals. Journal of Zoology, London, 203(4), 485-510.

Ramos-Neto, M.B. \& Pinheiro-Machado, C. (1996) O capim-flecha (Tristachya leiostachya Ness) e sua importância na dinâmica do fogo no Parque Nacional das Emas. In Impacto de Queimadas em áreas de Cerrado e Restinga (eds

H. S. Miranda, C. H. Saito and B. F. S. Dias), pp. 68-75. Editora Universidade de Brasília, Distrito Federal, Brazil.

Redford, K.H. (1985) ENP and the plight of the Brazilian cerrados. Oryx, 19(4), 210-214.

Ribeiro, M.B. (1994) Paleovegetação e paleoclima no quartenário tardio da Vereda de Águas Emendadas-DF. MSc thesis, Universidade de Brasília, Instituto de Geociências, Brasília.

Rodrigues, F.H.G. (1996a) História natural e biología comportamental do veado-campeiro (Ozotoceros bezoarticus) em cerrado do Brasil central. MSc thesis, Universidade Estadual de Campinas, Campinas, São Paulo, Brazil. 
Rodrigues, F.H.G. (1996b) Influência do fogo e da seca na disponibilidade de alimento para herbívoros do cerrado. In Impacto de Queimadas em Áreas de Cerrado e Restinga (eds H. S. Miranda, C. H. Saito and B. F. S. Dias), pp. 75-83. Editora Universidade de Brasília, Distrito Federal, Brazil.

Rosa, C.M.M. (1990) Recuperação pós-fogo do estrato rasteiro de um campo sujo de cerrado. MSc thesis, Universidade de Brasília, Brazil.

Sanaiotti, T.M. \& Magnusson, W.E. (1995) Effects of annual fires on the production of fleshy fruits eaten by birds in a Brazilian Amazonian savanna. Journal of Tropical Ecology, 11, 53-65.

Schaller, G. (1976) Notes on the Large Mammals of Parque Nacional das Emas, Brazil. Report to Instituto Brasileiro do Meio Ambiente e Recursos Naturais Renováveis, Brasília.

Shaw, J.H., Machado-Neto, J. \& Carter, T.C. (1987) Behavior of free-living giant anteaters (Myrmecophaga tridactyla). Biotropica, 19(3), 255-259.

Vieira, E.M. (1994) Efeito do fogo em comunidades de pequenos mamiferos de cerrado do Brasil Central. MSc thesis, Universidade Estadual de Campinas, Campinas, São Paulo, Brazil.

Warming, E. \& Ferri, M.G. (1973) Lagoa Santa e a Vegetaçao de Cerrados Brasileiros. Universidade de São Paulo, São Paulo, Brazil.

\section{Biosketches}

Leandro Silveira is a graduate student at Universidade Federal de Goiás, Brazil, with interests in carnivore ecology, conservation and management. Past research involved a study of Emas National Park's carnivore community. Current research involves carnivore conservation in fragmented cerrado areas.

Flávio H. G. Rodrigues is a graduate student at Universidade Estadual de Campinas, Brazil. He has led several projects that investigated cerrado fauna management and natural history. Current research aims to study the impacts of cerrado fragmentation on the mammalian fauna and the function of small reserves in the conservation of carnivores.

Anah Tereza de Almeida Jácomo is a graduate student at Universidade Federal de Goiás, Brazil, and has submitted a thesis on maned wolf ecology in Emas National Park. Current research involves large mammal management and conservation in fragmented cerrado areas.

José Alexandre F. Diniz Filho is a professor at Universidade Federal de Goiás and co-ordinator of the Graduate Programme in Biology. His major interests are in theoretical population biology. 